\title{
Reflections on Phishing for Phools: The Economics of Manipulation and Deception
}

\section{Thomas Klikauer}

\author{
University of Western Sydney. Sydney, Australia. t.klikauer@uws.edu.au
}

\begin{abstract}
Nobel Prize winning economists Akerlof and Shiller's phishing for phools explains the economics behind mass deception and manipulation in market economies. While "phishing" is commonly known as a form of internet fraught, their book 'takes a new, broader meaning, i.e. getting people to do things that are in the interest of the phisherman, but not in the interest of the target. A phool is someone who, for whatever reason, is successfully phished. These are emotional phools (feelings override common sense) and information phools (people act on information that is intentionally crafted to mislead them). Divided into "unpaid bills and financial crash", "phishing in many contexts", and "general lessons", the book uses rafts of examples from economics, the media, and advertising to substantiate their claim. While it avoids linking their findings to capitalism, the book contains a few helpful hints when seeking to avoid being "phished as a phool". In the end, and despite the economic analysis of the two Nobel Prize winners, the more illuminating book on the subject remains Lindstrom's "Buyology".
\end{abstract}

Keywords: cultural industry, mass deception, economics, manipulation, phishing, phools, advertising, capitalism

George A. Akerlof and Robert J. Shiller: Phishing for Phools - The Economics of Manipulation and Deception. Princeton University Press, 2015. xvi+272 pages. ISBN 9780691168319 (hardback).

Phishing for Phools' authors are two Nobel Prize winners - George Akerlof and Robert Shiller. Most recently, the value of the Nobel Prize became somewhat diminished when one Nobel Prize winner's gun ship - Barak Obama's - destroyed the hospital of another Nobel Prize winner (MSF 2015). Perhaps no longer indicating excellence, Nobel Prize-winners Akerlof and Shiller seek to describe the economics behind what Theodor W. Adorno and Max Horkheimer (1947) have, half a century ago, called "the cultural industry" and "mass deception". Key to Akerlof and Shiller is their challenge to the highly individualistic economic assumption of the homo oeconomicus - an idea or perhaps an ideology the authors confront in three parts: unpaid bills and financial crash; phishing in many contexts; and general lessons.

Astonishingly, phishing for phools seems to have, at least for Akerlof and Shiller, next to nothing to do with capitalism, a term suspiciously absent from the entire book. Instead, the authors claim that "inevitably, the competitive pressure for businessmen to practice deception and manipulation in free markets leads us to buy, and to pay too much for products that we do not need; to work at jobs that give us little sense of purpose; and to wonder why our lives have gone amiss" (vii). While this reminds one of the famous quote "we buy things we don't need with money we don't have to impress people we don't like", it is also reminiscent of the "bad apple" ideology under the hidden transcript: Capitalism is good, there are just a few bad apples in the box that manipulate us.

The word "phishing" is commonly used for Internet fraud as an attempt to acquire sensitive information such as usernames, passwords, and credit card details. It also includes attempts of fraud including money. Often this takes the form of someone masquerading as a trustworthy entity in an electronic communication (accounts@your.bank.com). A mild version occurs when details from www.ashleymadison.com are published online. More severe fraud emails imitate your bank while asking for your account details. Unlike these understandings, the book "takes a new, broader meaning for the word phish [...] it is about getting people to do things that are in the interest of the phisherman, but not in the interest of the target" (xi).

The second word is "phool" that the authors define as "someone who, for whatever reason, is successfully phished" (xi). This comes in two versions: In the case of the emotional 
phool, feelings override common sense, while in the case of the information phool, "people act on information that is intentionally crafted to mislead them" (xi).

Furnished with that, Akerlof and Shiller state the central aim of the book: "when there are complete free markets, there is not only freedom to choose; there is also freedom to phish" (5). Perhaps for Nobel Prize winners the idea that the free market creates pathologies is an astounding statement. For others it reminds of Marx and something that is essentially known since almost two-hundred years. More recently and since the advent of mass-consumerism, Vance Packard's "Hidden Persuaders" (1959) was for many "the" seminal attempt to explain the manipulative drive behind advertising. While Packard focused on manipulation in advertising, Akerlof and Shiller highlight the "behavioural economics" (6) side behind it.

The idea of Phishing for Phools is actually not so much economical, but behavioural, as it is manipulative, selling us the ideology of free choice while pre-shaping that same choice into the direction that is good for the phisherman but not for us. As a consequence, "the central prediction of this book [is that] free markets do not just produce what we really want; they also produce what we want according to our monkey-on-the-shoulder tastes. Free markets are also about producing those wants, so that we will buy what they have to sell" (20). While the authors are correct when noting "the idea of tempting the consumer to buy, to spend their money, is in the very nature of free markets themselves" (21), capitalism is neither natural nor does it lead the authors to question the manipulative system of consumer capitalism. This is a system that - to a very large extent - is not about selling bread and butter but all the things we do not need.

Even though Akerlof and Shiller go into the institutional details of capitalism showing, for example, that "one ratings agency, Moody's, gave 45,000 mortgage-related securities a triple-A rating for the period between 2000 and 2007" (34) shortly before the Global Financial Crisis (GFC), the authors fail to mention that many home loans were actually sold by dodgy sellers and half criminals. What they also avoid mentioning is that most, if not all, participation in the "ruthless game" (Drucker 2009:19) of capitalism shares the same interest. There might just be an interest symbiosis between those corporations selling faulty mortgages, those certifying it, those financing it, and those media corporations telling us "all is fine" until the infamous "sh"*** hits the fan" and someone else pays the bill. When someone else pays the bill, economists call this "externality" - offloading the negative onto others. The banks and financial corporations have learned their lessons from the GFC. Now they know: We can get away with it (Luyendijk 2015:28). This is sold to us as "too big to fail" - or perhaps "too big to jail".

What this means at an individual level is shown by Goldman Sachs' Josh Birnbaum saying, "I guess it depends on your perspective of what's fair, right?" (35). Statements like these not only highlight the MADD - moral attention deficit disorder (Klikauer 2015) of capitalism's henchmen called managers, it also makes a mockery of the hallucinogenic business ethics belief in individual managers' responsibility that is paraded in almost any business ethics textbook (Klikauer 2013, 2015). But offloading negatives onto others has a long and continuing tradition in management. This is shown, when for example, "United Airlines found that its assets had less value than its liabilities in the fall of 2002" (35). Their management just "found" (!) that its assets had less value. It had nothing to do with a deliberate management strategy and Managerialism. And it had nothing to do with the offloading of the cost of all this onto others: "labour unions [agreed to] more than $\$ 3$ billion annually in wage cuts" (35).

This is actually a good example for what Akerlof and Shiller describe the following way: "[l]t's not just that we acquire new information; we change our point of view and we interpret information in new ways [and this is where not just] advertising as storytelling" (45-46). Managerialism makes us believe that offloading $\$ 3 b n$ onto workers is good. Similarly, we are made to believe that a mixture of "palm oil and olive oil: Palmolive" (50) is good for us. In short, "advertisements were successful because narratives from these ads were grafted onto the customer's own" (53). This is something that is not, as Akerlof and Shiller suggest, an issue of the past. It is very much with us today.

To analyse the effectiveness of advertising, statistical testing remains imperative. Such "statistical testing may have begun in Benton Harbour with coupons for Palmolive [...] in a primi- 
tive way in [...] 1920; but the Obama campaign of 2002 showed its use as a new art form" (55). While such feedback loops remain essential for commercial and political advertising, phishing for phools is also used, for example, to phish in the mundane showroom when selling cars. "[W]hite women were given a quote of $\$ 246$ (inflation-adjusted) more than white men; black women, $\$ 773$ more; and black men $\$ 2,036$ more" - all this started to work when salespeople noticed "who is less likely to walk away from a bad deal" (60). Two things can be learned from this: do not have an 'ideal car in mind [and] don't, don't', don't mention that you have a trade-in until after you've negotiated a price" (62). While these are interesting ideas one can get from Akerlof and Shiller's book, what the book never does is relating its wealth of information and insights to the pathologies of capitalism.

Needless to say that phishing for phools is exploited much more ruthlessly when credit cards become the name of the game. But it also works in phishing for politics - another money game. In this game, "a representative must raise roughly $\$ 1,800$ per day in office (Saturdays, Sundays, and holidays included)" to pay for his or her election (73). But perhaps the real phishing for phools takes place between politicians and the "12,000 lobbyists [of Washington], which is more than twenty for each member of Congress" (77). The numbers are similar for almost any country's seat of government. But the "politician-\&-money" link goes further; 'in the class of congressional retirees for 2010, a full 50 percent of senators and 42 percent of representatives became lobbyists' (79) signifying the old truth "we have the best politicians money can buy".

And these lobbyists/politicians work hard to defend their - not our - interest when it comes, for example, to food labelling, making sure that "cranberry juice" [must not] "be labelled 75 percent water [...] by 2005 , US sales of cranberry juice had topped $\$ 750$ million [...] the costs of lobbying, in contrast, were minuscule" (81). Akerlof and Shiller, however, do not mention a more important case: "when the EU, for example, made a modest proposal to introduce a simple 'traffic light' food labelling system (green = good, yellow = sometimes, red $=$ bad) in order to signal food high in sugars and fats, food industry lobbyists quickly persuaded politicians of the error of their idea. The "'Confederation of the Food and Drink Industries' spent an estimated $\$ 1.3$ billion in order to successfully oppose the change, thereby vastly outnumbering and outspending consumer and health campaigners" (Klikauer 2013, 238). As a consequence, food labelling was shelved. This is how the "political" economy works.

While standard economics - freed from the word "political" to ideologically de-politicise economics - continues to peddle the "free market" ideology, phishing for phools works best in such unregulated and deregulated markets as Akerlof and Shiller show in respect to food and drugs. But the idea that neo-liberalism's hegemonic ideology of a free market does not work dates back to one key rectifying instrument, the "Pure Food and Drug Act of 1906" (84). The longstanding interface between the media and capitalism - perhaps seen as "media capitalism" - works even better when "Big Pharma" is involved, as Akerlof and Shiller's example of Merck's Vioxx shows. Merck is a corporation that was "for six consecutive years [named] Fortune's Most Admired firm" (86). There was quite similar high praise for Enron, until the day it spectacularly collapsed. Akerlof and Shiller highlight how Big Pharma manipulates research that is published in "scientific" journals often owned and run by global media corporations and used to deceive medical doctors in prescribing certain drugs sold to them in elaborate "conferences" at exotic locations under the motto "everyone is in on the take". Akerlof and Shiller argue that in respect to this example, there were "deaths conservatively estimated in excess of 26,000" (90). Another externality!

The pharma example, of course, includes academics in medicine because profit imperatives extend deep into academia (Monbiot 2011): 'the latest edition of Gregory Mankiw's (excellent) textbook, Principles of Economics, is $\$ 361.95$, but you can get it at a bargain, on Amazon, for only $\$ 315.15 "(95)$. In a rare albeit mild moment of self-reflection, Akerlof and Shiller note, "free market capitalism does not just give us our current abundance of goods and services from people trading according to their comparative advantage; it also gives us ever-increasing abundance through the application of new ideas [leading the author's to] Hallelujah economics" (97). In contrast to capitalism's affirmative Hallelujah economics, Aker- 
lof and Shiller's version of economics "means that we can figure out how to lure people into doing things that are in our interest, but not in theirs [setting] good-for-you/good-for-me [against] good-for-me/bad-for-you" (98).

But perhaps the greatest example of phishing for phools remains tobacco, which, unmentioned by Akerlof and Shiller, killed roughly 100 million people during the $20^{\text {th }}$ century (Benson and Kirsch 2010). Furnished with stratospheric global profits for decades, Akerlof and Shiller emphasise, "tobacco companies agreed to pay $\$ 206$ billion for expenses" (108). It appears that US $\$ 206,000,000,000$ is a respectable sum for corporations. But when one considers the multi-billion profits that corporations made during the course of the century, the sum is very manageable for such corporations.

At least it was not so damaging that "RJR Nabisco's tobacco subsidiary's CEO Edward Horrington [received a] $\$ 45.7$ million golden parachute" (124). Necrocapitalism (Banerjee 2008) seems to work. But it is not just profit for death, the "free market system brings ever more sophisticated manipulations and deceptions" (136).

Despite all this and what Akerlof and Shiller do not mention (e.g. corporatewatch.org), the authors still claim "directors of large US corporations are remarkably sensitive to their reputations: 'the most reputationally sensitive people in the world'" (141). This myth can be kept up when, for example, one does not mention the CEO of the "Tyco Corporation who had spent $\$ 6,000$ for a shower curtain" (Klikauer 2013, 268), "CEOs [...] showering themselves with lots of money" (Chorafas 2014, 15); and Bhopal's official immediate death toll of 2,259 easily measuring up to 9/11's 2,996 deaths. In 2002, Bhopal causing CEO Warren Anderson - as an example of corporate social responsibility or the lack of it - "was discovered by a UK newspaper living a life of luxury in New York State (US). Despite being wanted by India and Interpol, US authorities have made no effort to extradite Anderson, claiming they are unable to find him" (Greenpeace 2009). When Greenpeace visited his mansion, he preferred to hide while his wife claimed "he is a good man". These are just some of the most "reputationally sensitive people in the world", as Akerlof and Shiller seek to make us believe.

This myth or ideology is rehearsed when Akerlof and Shiller claim that some corporations have "161/4-page, single-spaced codes of ethics" (141). Enron had 64 pages of ethics codes until George W. Bush's friend "Kenny Boy", (former) Enron CEO Kenneth Lay was handcuffed. When phishing for phools, the general public is easily phooled by the "Servants of Power" (Baritz 1960) of business ethics and Nobel Prize winning economists. Consciously or unconsciously, many academics are made to be part of the manipulation as "pickpockets and magicians" (149).

As a conclusion, the authors note "phishing for phools examines the role of markets when people have weaknesses, so markets are not efficient; and those with the weakness can, potentially, be tricked and fooled" (164). This is Akerlof and Shiller's contribution to today's rather standard - and one might say neo-liberalism's - economics that still propagates the ideology that "people only make the choices that maximise their welfare. This assumption even has a fancy name: revealed preferences" (170). Akerlof and Shiller close by writing that "there may be nothing in this book that could be considered new economics" (173), which is perhaps a rather true statement. But it remains a rather sad truth that when one seeks to understand phishing for phools, it is not so much the book of two Nobel Prize winners that gives the deepest insights, but advertising insider Lindstrom's (2008) book "Buyology" (2008) that most exquisitely explains how phishing for phools is done.

\section{References}

Banerjee, Subhabrata Bobby. 2008. Necrocapitalism. Organization Studies 29 (12): 1541-1563.

Baritz, Loren. 1960. The Servants of Power. A History of the Use of Social Science in American Industry. Middletown: Wesleyan University Press.

Benson, Peter and Stuart Kirsch. 2010. Capitalism and the Politics of Resignation. Current Anthropology 51 (4): 459-486.

Chorafas, Dimitris N. 2014. Business Efficiency and Ethics: Values and Strategic Decision-Making.

New York: Palgrave-

Drucker, Peter F. 2009. Concept of the Corporation. New Brunswick: Transaction Publishers. 
Greenpeace 2009. Bhopal Timeline, www.greenpeace.org/international/en.

Horkheimer, Max and Theodor W. Adorno. 1947. Dialectic of Enlightenment. London: Verso.

Klikauer, Thomas. 2013. Managerialism - Critique of an Ideology. Basingstoke: Palgrave.

Klikauer, Thomas. 2013. Philosophy, Business Ethics and Organisation Theory: A Review Article. Philosophy of Management 12 (1): 79-87.

Klikauer, Thomas. 2015. Morality, Competition, and the Firm: The Market Failure, Approach to Business Ethics, Philosophy of Management 14 (2): PAGE RANGE MISSING

Lindstrom, Martin. 2008. Buyology: Truth and Lies about why we Buy. New York: Doubleday.

Luyendijk, Joris. 2015. It's Business as Usual in Our Banking System. The Guardian Weekly, $23^{\text {rd }}$ October 2015, 26-28.

Monbiot, George. 2011. Academic Publishers Make Murdoch Look like a Socialist, www.theguardian.com, Tuesday $30^{\text {th }}$ August 2011.

MSF- 2015. Kunduz Hospital Air Strike, www.msf.org/topics/kunduz-hospital-airstrike.

Packard, Vance O. 1959. The Hidden Persuaders. New York: McKay.

\section{About the Author}

Thomas Klikauer

Thomas Klikauer teaches MBA students at the Sydney Graduate School of Management (University of Western Sydney, Australia). He is the author of "Managerialism" (Palgrave 2013), six other books and numerous articles. Currently, he is working on a book called "media capitalism". 